\title{
Comprehensive medication management of kidney transplanted patients
}

\author{
Gerenciamento da terapia medicamentosa em transplantados renais \\ Manejo de la farmacoterapia en receptores de trasplante de riñón
}

Received: 01/27/2022 | Reviewed: 01/31/2022 | Accept: 02/01/2022 | Published: 02/03/2022

\author{
Patrícia Mara dos Reis \\ ORCID: https://orcid.org/0000-0003-3747-6072 \\ Universidade Federal de Minas Gerais. Brasil \\ E-mail: reis.patriciamara@gmail.com. \\ Isabela Diniz Gusmão de Oliveira \\ ORCID: https://orcid.org/0000-0002-5452-4753 \\ Universidade Federal de Minas Gerais, Brasil \\ E-mail: isabela.gusmao@gmail.com \\ Pollyanne Lacerda Coelho \\ ORCID: https://orcid.org/0000-0003-0097-2216 \\ Universidade Federal de Minas Gerais, Brasil \\ E-mail: pollyanne-lacerda@ hotmail.com \\ Sílvia Novaes Dias \\ ORCID: https://orcid.org/0000-0002-8224-2817 \\ Universidade Federal de Minas Gerais, Brasil \\ E-mail: sil_vianovaes@hotmail.com \\ Luana Kellen de Oliveira Silva \\ ORCID: https://orcid.org/0000-0002-5540-8877 \\ Universidade Federal de Minas Gerais, Brasil \\ E-mail: lu_kellen@hotmail.com \\ Clarice Chemello \\ ORCID: https://orcid.org/0000-0002-1234-1561 \\ Universidade Federal de Minas Gerais, Brasil \\ E-mail:clachemello@gmail.com
}

\begin{abstract}
Kidney transplant patients use several medications, which increases the risk of developing drug-related problems. This is a pre-post-intervention study, carried out in a transplant outpatient clinic in Belo Horizonte, Minas Gerais, Brazil, with post-transplant patients using tacrolimus. Pharmacy consultations were carried out in individual offices, and the initial and final status were measured between the first and the last consultation. Satisfaction with the pharmaceutical service was also assessed. Thirty-nine drug-related problems were identified, $64.3 \%$ of patients presenting at least one, of which $79.5 \%$ were resolved $(\mathrm{p}<0.001)$. The most frequent were "use of unnecessary medications" $(26.5 \%)$, with omeprazole being the most prescribed medication for this situation. Polymedicated patients had more drug-related problems $(\mathrm{p}=0.001) .49$ interventions were performed, $51.02 \%$ were accepted. The most accepted interventions were recommendations for guidelines regarding the time of administration and reduction of adverse drug reactions (100\%) and suspension of treatment $(92.3 \%)$. In the end, the proportion of patients with stable clinical status increased from $35.7 \%$ to $83.3 \%$ ( $\mathrm{p}<0.001$ ). Patients related the pharmaceutical service as very good, reporting the desire for its continuity. Comprehensive medication management positively impacted the patient's clinical situation, proved to be effective in solving drug-related problems, and was very well evaluated by the patients. It is recommended that polymedication is a priority criterion for this service.
\end{abstract}

Keywords: Kidney transplantation; Pharmaceutical services; Medication therapy management; Patient satisfaction; Drug related problems.

\section{Resumo}

Pacientes transplantados renais utilizam diversos medicamentos, o que aumenta o risco de desenvolver problemas relacionados a medicamentos. Trata-se de um estudo pré-pós-intervenção, realizado em um ambulatório de transplantes em Belo Horizonte, Minas Gerais, Brasil, como pacientes no pós-transplante e em uso de tacrolimo. As consultas farmacêuticas foram realizadas em consultórios individuais, sendo que estado inicial e final foram medidos entre a primeira e a última consulta. A satisfação com o serviço farmacêutico também foi avaliada. Foram identificados 39 problemas relacionados a medicamentos, $64,3 \%$ dos pacientes apresentando pelo menos um, dos quais $79,5 \%$ foram resolvidos $(\mathrm{p}<0,001)$. Os mais frequentes foram "uso de medicamentos desnecessários" $(26,5 \%)$, sendo o omeprazol o medicamento mais prescrito para essa situação. Os pacientes polimedicados apresentaram mais problemas relacionados ao medicamento $(\mathrm{p}=0,001)$. Foram realizadas 49 intervenções, $51,02 \%$ foram aceitas. As 
intervenções mais aceitas foram recomendações de orientações quanto ao tempo de administração e redução de reação adversa medicamentosa (100\%) e suspensão do tratamento $(92,3 \%)$. Ao final, a proporção de pacientes com quadro clínico estável a condição aumentou de 35,7\% para 83,3\% (p <0,001). Os pacientes avaliaram o atendimento farmacêutico como muito bom, relatando o desejo de sua continuidade. O gerenciamento da terapia medicamentosa impactou positivamente na situação clínica do paciente, demonstrou ser eficaz na resolução de problemas relacionados a medicamentos e foi muito bem avaliado pelos paciente. Recomenda-se que a polimedicação seja critério prioritário para a implantação do gerenciamento da terapia medicamentosa.

Palavras-chave: Transplante renal; Serviços farmacêuticos; Gerenciamento da terapia medicamentosa; Satisfação do paciente, Problemas relacionados ao uso de medicamentos.

\section{Resumen}

Los pacientes con trasplante de riñón usan varios medicamentos, lo que aumenta el riesgo de desarrollar problemas relacionados con los medicamentos. Se trata de un estudio pre-postintervención, realizado en un ambulatorio de trasplantes en Belo Horizonte, Minas Gerais, Brasil, con pacientes postrasplante que utilizan tacrolimus. Las consultas farmaceuticas se realizaron en consultorios individuales y se midió el estado inicial y final entre la primera y la última consulta. También se evaluó la satisfacción con el servicio farmacéutico. Se identificaron 39 problemas relacionados con el fármaco, el 64,3\% de los pacientes presentó al menos uno, de los cuales se resolvió el 79,5\% (p <0,001). Los más frecuentes fueron el "uso de medicamentos innecesarios" (26,5\%), siendo el omeprazol el medicamento más prescrito para esta situación. Los pacientes polimedicados tenían más problemas relacionados con los fármacos $(\mathrm{p}=$ 0,001). Se realizaron 49 intervenciones, se aceptaron el 51,02\%. Las intervenciones más aceptadas fueron las recomendaciones de guías en cuanto al tiempo de administración y reducción de reacciones adversas a medicamentos (100\%) y suspensión del tratamiento (92,3\%). La proporción de pacientes con estado clínico estable pasó de 35,7\% al 83,3\% ( $\mathrm{p}<0,001$ ). Los pacientes calificaron el servicio farmacéutico como muy bueno, informando el deseo de su continuidad. El manejo de la terapia con medicamentos tuvo un impacto positivo en la situación clínica del paciente, demostró ser eficaz para resolver los problemas relacionados con los medicamentos y fue muy bien evaluado por el grupo. Se recomienda que la polimedicación sea un criterio prioritario para este servicio.

Palabras clave: Trasplante de riñón; Servicios farmacéuticos; Satisfacción del paciente; Problemas relacionados con los medicamentos.

\section{Introduction}

Renal transplantation is a treatment modality available for patients in the final stage of chronic kidney disease (CKD) (Brasil, 2021; Prates et al., 2016) and is associated with higher survival rates, better quality of life, and lower costs compared to hemodialysis (Berns, 2020; Molnar- Varga et al., 2011; Schunelle et al., 1998). However, this patient lives with the possibility of rejection of the graft, the need of a lifestyle changes and continued use of medications to maintain immunosuppression (Naik, 2020; Prates et al., 2016; Brito et al., 2016). Beyond the immunosuppressants, the patient uses several other medications to treat concomitant diseases, which increases the risk of developing drug-related problems (DRP), negatively impacting graft and patient survival (Chisholm-Burns et al., 2016; Lee et al., 2016).

Ideally, pharmacotherapy for clinical problems should be the most indicated, effective, safe and convenient for the individual. These pillars support the comprehensive medication management (CMM) "defined as the standard of care that ensures each patient's medications (whether they are prescription, nonprescription, alternative, traditional, vitamins, or nutritional supplements) are individually assessed to determine that each medication is appropriate for the patient, effective for the medical condition, safe given the comorbidities and other medications being taken, and able to be taken by the patient as intended". In this process, clinical pharmacists work in collaboration with other professionals to optimize patient outcomes in four steps: assessment of the patient, evaluation of medication therapy, development e initiation of plan and follow up and medication monitoring (ACCP, 2021; Lee et al., 2016; Oliveira, 2011).

The clinical and humanistic impacts of the CMM applied to this study refer to the improvement in laboratory and symptomatic parameters related to the use of prescription and non-prescription drugs and the patient's subjective experience for pharmaceutical interventions and services provided (ACCP, 2021; Joost et al., 2014; Cipolle, Strand and Morley, 2012) .

Studies with renal transplant patients have shown the importance of the pharmacist in the multidisciplinary team, acting mainly in adherence problems, pharmacotherapy review and post-discharge hospital guidance (Manyama, Tshitake, and 
Moloto, ,2020; Leite et al.,2018; Joost el al., 2014; Lee et al., 2016; Lima et al., 2016). However, the pharmacist participation in the outpatient follow-up of renal transplant patients is still incipient in Brazil.

Satisfaction can be used as effectiveness indicator of a service. The satisfaction survey involves the user's subjective perception about the care received and identifies the aspects that need greater attention, seeking options to adjust care to their needs. The existence of measures to identify the aspects that affect satisfaction become increasingly important, helping to guide strategies to improve the quality of care (Acosta et al., 2016).

Considering the complexity of the chronic treatment of immunosuppression in kidney transplantation, concomitant use of other drugs that may alter drug therapy, in addition to the advantages of pharmaceutical monitoring to prevent DRP in chronic diseases. Analyzing the few studies on outpatient follow-up of these patients by pharmacists in Brazil, it is hoped that the results of these studies may encourage the clinical and practical performance of this professional to optimize the therapeutic goals of renal transplant recipients.

So, this propose is to evaluate pharmacotherapeutic needs of the individual, in a holistic way, and has the pharmacist as an essential professional in the identification and resolution of DRP.

\section{Methodology}

This work was approved by the research ethics committee of the Federal University of Minas Gerais and the hospital (CAAE number 56059216.8.0000.5149), in July 2016. All participants have signed the Informed Consent Form.

This is a pre-post intervention study conducted from November 2016 to August 2018 at the transplantation outpatient clinic of a large hospital in Belo Horizonte, Minas Gerais, Brazil. The study included patients with post-transplant time from 18 days to 18 months on tacrolimus use, which were chosen according to the schedule sent by the outpatient team that provided information about time of transplantation of these patients. Were measured drug related problem (DRP) in the same patient before and after the pharmacist intervention. The pharmacists approached these patients and checked if they use tacrolimus as an immunosuppressive therapy. This research is part of a project "Integration of tacrolimus pharmacogenetics on medication therapy management (MTM) in kidney transplant recipients" (de Oliveira et al., 2021). Patients who underwent transplantation in other organs, kidney de novo transplant recipients, and those with advanced liver disease were excluded.

The main outcomes refer to changes in clinical status according to Cipolle, Strand and Morley (2012). The first appointments were initial state, considering all the clinical and medication analyzed. And the final status was measured at the last pharmaceutical appointment (Cipolle, Strand and Morley, 2012).

The Pharmacotherapy Work-up (PW) method of CMM was used (Cipolle, Strand and Morley, 2012; Oliveira, 2011). The date of the appointments was registered in a specific form. The appointments were done individually, in a private room, on the same days of these patients' medical appointments in the outpatient clinic; each patient had at least three appointments with the pharmacist. After which appointments, the researchers established the intervention priorities according to the identification of DRP, which could occur between the first and the last follow-up appointments. The DRP were classified according to Cipolle, Strand and Morley, 2012 (Cipolle, Strand and Morley, 2012; Oliveira, 2011). Data referring to laboratory tests and clinical procedures were collected from the patient's chart. The interventions aimed at resolving DRP, achieving therapeutic results from immunosuppressive and drugs therapy for other diseases and preventing future clinical problems.

The patient's clinical status was analyzed between the first and last visit, being classified as: initial, resolved, stable, partial improvement, improvement, without improvement and worsening, according to the clinical parameters of his health problems (Cipolle, Strand and Morley, 2012). Polymedication was classified as non-polymedicated, minor polymedicated and major polymedicated (Bjerrum et al., 1999). 
After the last appointment, the patient's satisfaction with the CMM was evaluated by applying the Pharmaceutical Services Satisfaction Questionnaire (PSSQ) developed for Larson et al (2002), translated and validated to Brazilian Portuguese for Correr et all (2009) (Correr et al., 2009; Larson et al., 1996). Other researchers who did not participate in previous pharmacotherapeutic follow-up applied the questionnaire. The PSSQ score was calculated using the five-point Likert scale according to the original instrument: $1=$ bad, $2=\operatorname{regular}, 3=\operatorname{good}, 4=$ very good and $5=$ excellent. For the whole instrument, or for each domain, the score is calculated by the sum of the user responses divided by the number of corresponding questions.

Data were analyzed using SPSS software version 24. Descriptive analysis of variables was done by frequency and percentage of qualitative variables and mean \pm standard deviation for quantitative variables. Comparative analysis of pre-post intervention clinical status and association between polypharmacy and DRP was done using Pearson's $\mathrm{X}^{2}$ Test. The comparison between the means of DRP pre-post intervention was analyzed by Student's paired t-test. Univariate analyses were performed using test or Fisher's exact test when the expected value of one or more cells was five or less. Only polypharmacy showed $\mathrm{p}<0.15$ in the univariate analyses so we could not to perform a multivariate model. Confidence interval was of $95 \%$ and the results were considered statistically significant when $\mathrm{p}<0.05$.

\section{Results}

From 44 patients invited on the day of the periodic medical consultations performed at the outpatient clinic, 42 accepted to participate in the study, of which $57.1 \%$ were men. Regarding the age, $28.6 \%$ of the transplant recipients with $80.9 \%$ of deceased donors and between 51 and 60 years old and 38\% were between 181 and 360 days.

The mean age was $44.9( \pm 13.3)$ years. It was observed that women were younger $(39.8 \pm 13.1$ years $)$ than men (47.3 \pm 13.9$)$. Regarding the self-declared race, the brown predominated, corresponding to $40,5 \%$. Demographic data are described in Table 1. 
Table 1. Sociodemographic data of patients $(n=42)$.

\begin{tabular}{|c|c|c|}
\hline Variable & $\mathbf{n}$ & $(\%)$ \\
\hline \multicolumn{3}{|l|}{ Sex } \\
\hline Female $^{\mathrm{a}}$ & 18 & 42.9 \\
\hline Male $^{\mathrm{b}}$ & 24 & 57.1 \\
\hline \multicolumn{3}{|l|}{$\operatorname{Age}^{\mathrm{d}}$} \\
\hline 20 to 30 years & 09 & 21.4 \\
\hline 31 to 40 years & 11 & 26.2 \\
\hline 41 to 50 years & 04 & 9.5 \\
\hline 51 to 60 years & 12 & 28.6 \\
\hline$>60$ years & 06 & 14.3 \\
\hline \multicolumn{3}{|l|}{ Transplantation time $^{\mathrm{c}}$} \\
\hline 18 to 90 days & 8 & 19 \\
\hline 90 to 180 days & 13 & 31 \\
\hline 181 to 360 days & 16 & 38 \\
\hline 361 to 510 days & 5 & 12 \\
\hline \multicolumn{3}{|l|}{ Race } \\
\hline White & 9 & 21.4 \\
\hline Brown & 17 & 40.5 \\
\hline Black & 8 & 19.1 \\
\hline Undeclared & 8 & 19.1 \\
\hline \multicolumn{3}{|l|}{ Health services } \\
\hline Mixed & 5 & 11.9 \\
\hline Public & 37 & 88.1 \\
\hline \multicolumn{3}{|l|}{ Scholarity } \\
\hline Unlettered & 1 & 2.4 \\
\hline Incomplete elementary school & 3 & 7.1 \\
\hline Complete elementary school & 8 & 19.1 \\
\hline Incomplete high school & 4 & 9.5 \\
\hline Complete high school & 18 & 42.9 \\
\hline Incomplete higher education & 3 & 7.1 \\
\hline Complete higher education & 3 & 7.1 \\
\hline Undeclared & 2 & 4.8 \\
\hline \multicolumn{3}{|l|}{ Marital status } \\
\hline Separate & 6 & 14.3 \\
\hline Single & 8 & 19.1 \\
\hline Stable union / married & 26 & 61.9 \\
\hline Widower & 02 & 4.8 \\
\hline \multicolumn{3}{|l|}{ Occupation } \\
\hline Retired & 14 & 33.3 \\
\hline Active & 15 & 35.7 \\
\hline Benefit LOAS ${ }^{\mathrm{d}}$ & 6 & 14.3 \\
\hline Housewife & 3 & 7.1 \\
\hline Student & 4 & 9.5 \\
\hline \multicolumn{3}{|l|}{ Donor Type } \\
\hline Alive & 8 & 19.1 \\
\hline Deceased & 34 & 80.9 \\
\hline
\end{tabular}

a,b,c Missing date ${ }^{\mathrm{d}}$ Law of Social Assistance. Fonte: Authors (2022).

A mean of $3.1 \pm 1.1$ appointments per patient was performed, with the mean follow-up time being $8 \pm(4.1)$ months. This number varied according to the clinical condition of the patients, as some doctors recommended the return in periods longer than a month. Appointments after the initial evaluation of six patients were canceled in situations where there were no available offices, causing loss of follow-up. 
All patients reported having a family history of kidney disease, and most the diagnosis was about 10 years ago (40.5\%) and $85.7 \%$ had hemodialysis as pre-transplant renal replacement therapy.

It was observed that $54.8 \%$ of patients had up to two concomitant diseases, in addition to transplantation, among them hypertension (47.6\%), gastric disorders (11.9\%), diabetes (7.1\%), hypercholesterolemia, (7.1\%) and epilepsy (2.4\%). Hypertension was the main known cause of CKD that took $40.5 \%$ of the patients in this study to renal transplantation. Other causes for the transplantation were glomerulonephritis and diabetes (11.9\% both).

The majority of patients $(97.6 \%)$ used three transplant medications and the average number of medications to treat other health problems was $3.7 \pm 2.1$. In this way, $16.7 \%$ of the patients were considered minor polymedicated and $83.3 \%$ major polymedicated, using a mean of $6.6 \pm 2.1$ medications. According to Bjerrum et al (1999), the use of five or more medications simultaneously increases the risk of adverse reactions, medication errors and increased risk of hospitalization (Bjerrum L et al., 1999).

Were identified 39 DRP, which 69.2\% (27) of the patients presented at least one and 79.5\% (31) were resolved $(\mathrm{p}<0.001)$. Patients who had at least two DRP, took more than five medications (major polymedicated), thus, polymedication could be considered a predisposing factor for DRP $(\mathrm{p}<0.001)$.

Forty-nine interventions were performed, which 53\% (26) were accepted. The main diseases involved in the interventions were hypertension (36.7\%), gastric disorder (24.5\%) and transplantation (8\%). The most frequent accepted interventions were recommendations for guidance on administration time and to soften adverse drug reactions (100\%), recommendation to suspend treatment $(92.3 \%)$, recommendation to adhere to pharmacological treatment $(43.7 \%)$. Table 2 describes the interventions by health problem, medication and DRP. 
Table 2. Relationship of health problems with medications involved, DRP and interventions.

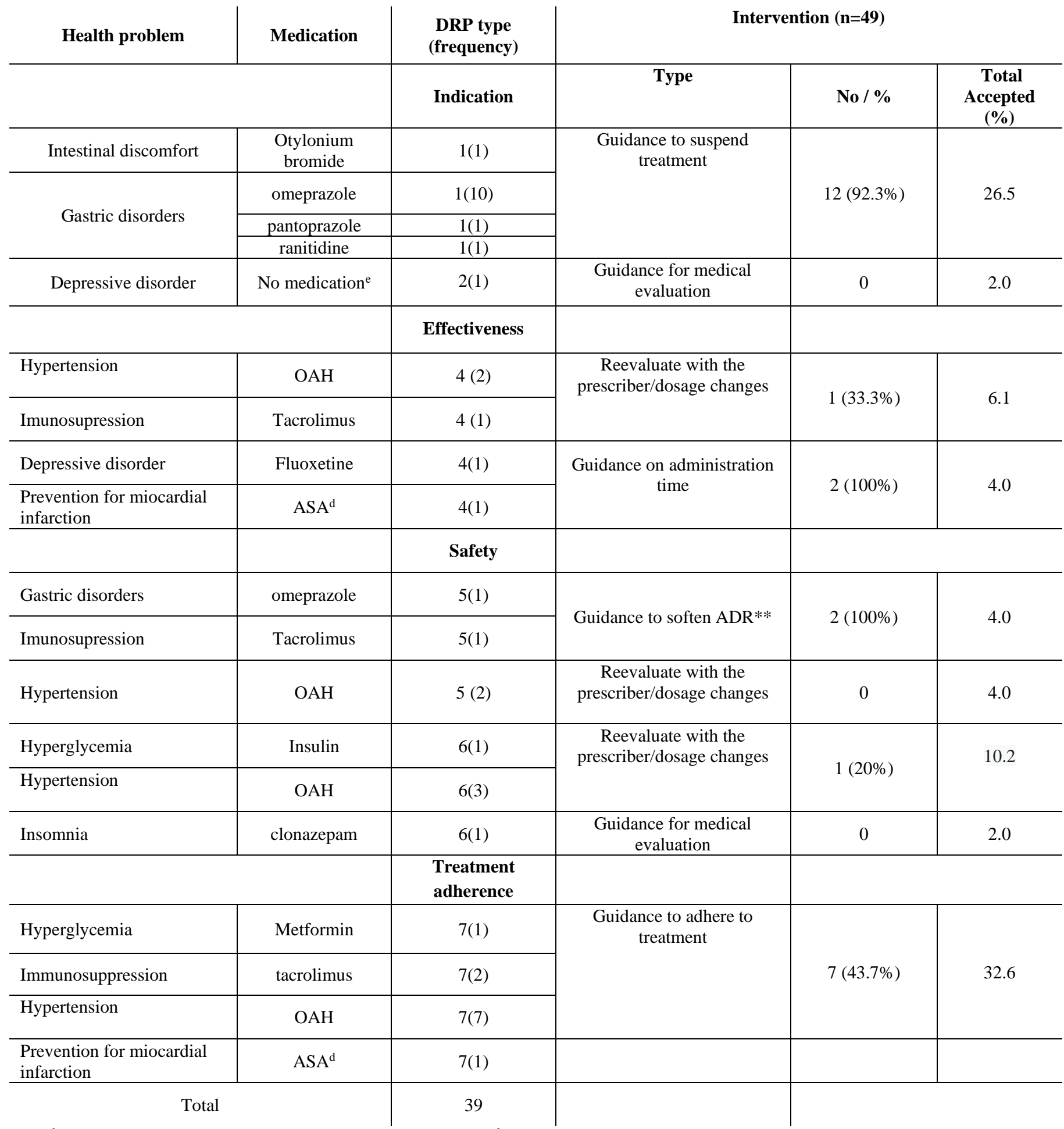

bOAH: Oral antihypertensive; ${ }^{\mathrm{b} A D R}$ : adverse drug reaction; ${ }^{\mathrm{d}}$ Acetil Salicilic Acid ${ }^{\mathrm{e}}$ Untreated health problem. Fonte: Authors (2022)

Only one of eight patients with 18 days to 3 months of transplantation time had DRP and it was resolved. There was $100 \%$ resolution of DRP in patients with up to 6 months of transplantation $(\mathrm{p}<0.0001)$. The 16 patients with transplantation time between 6 and 12 months together had 25 DRP at the beginning of the CMM and at the end, 19 DRP were resolved $(\mathrm{p}=$ 0.001). It can therefore be inferred that the longer the transplant time, the greater the number of DRP and the CMM can resolve them. 
Fifteen patients maintained their stable clinical situation, of the 26 individuals with initial clinical status "worsened" according to the disease, $21(80.8 \%)$ improved their condition $(\mathrm{p}<0.001)$. The proportion of patients with stable clinical condition increased from $35.7 \%$ to $83.3 \%$ ( $<<0.001)$.

Of the $42 \mathrm{CMM}$ patients, 30 responded to the PSSQ. The overall mean was $4.32 \pm 0.71$ and the CMM service was considered "very good". Patients with more consultations were more satisfied $(\mathrm{p}<0.001)$. The "excellent" response was more frequent in items 5, 7, 9 and 12 (Table 3).

Table 3. Patients`satisfaction with ambulatory CMM.

\begin{tabular}{lc}
\hline \multicolumn{1}{c}{ QUESTIONS } & Mean \pm SD \\
\hline Q1. The pharmacist's ability to warn you about problems you might have with your medications? & $4.2 \pm 0.7$ \\
Q2. The pharmacist's explanation of the action of his medications? & $4.3 \pm 0.7$ \\
Q3. The pharmacist's interest in your health? & $4.3 \pm 0.7$ \\
Q4. The pharmacist's help in the use of your medicines? & $4.2 \pm 0.8$ \\
Q5. The commitment of the pharmacist to solve the problems you have with your medications? & $4.4 \pm 0.7$ \\
Q6. The responsibility that the pharmacist assumes with his treatment? & $4.3 \pm 0.7$ \\
Q7. The pharmacist's guidances on how to take your medications? & $4.3 \pm 0.8$ \\
Q8. The pharmacist's commitment to maintaining or improving your health? & $4.2 \pm 0.6$ \\
Q9. Privacy in conversations with your pharmacist? & $4.5 \pm 0.6$ \\
Q10. The pharmacist's commitment to ensuring that his or her medications have the expected effect? & $4.2 \pm 0.6$ \\
Q11. The pharmacist's explanation of the possible adverse effects of the medicines? & $4.3 \pm 0.6$ \\
Q12. The time the pharmacist offers to spend with you? & $4.4 \pm 0.8$ \\
\hline Global satisfaction & $\mathbf{4 . 3 \pm 0 . 7}$ \\
\hline
\end{tabular}

Fonte: Authors (2022).

\section{Discussion}

The proportion of renal transplant patients who had at least one DRP (69.2\%) was smaller than Welch et al (2009). Mendonça et al (2016) and Detoni et al (2017) found similar data in studies (Detoni et al., 2017; Mendonça et al., 2016) Thus, major polymedicated patients should be included preferentially in the CMM service, in order to avoid the onset of DRP.

These findings reinforce the need for constant monitoring of these patients by the potential incidence of DRP. The number of concomitant diseases, age, diagnosis of hypertension, diabetes, dyslipidemia did not present a statistically significant relation with the number of total DRP found. However, transplantation time did. It could be related to the patient's monitorization, because until the first 3 months after the procedure, the medical consultations should be weekly for dose adjustment of immunosuppressants through blood concentration, as recommended by the Brazilian protocol for immunosuppression in kidney transplantation (Brasil, 2021).

The most frequent DRP were "unnecessary drug use" (26,5\%). Omeprazole was the drug most frequently associated with unnecessary use $(76.9 \%)$. In the post-transplantation, due to the use of immunosuppressants, prophylaxis of gastric disorders with a proton pump inhibitor, mainly omeprazole, is common. However, the drug ends up being used chronically, without reassessment as to the necessity of continuity or not of the therapy. According to the literature, there are reports of risks associated with the chronic use of proton pump inhibitors (Farrel et al., 2019; 2017; Ho et al., 2017; Elaine et al.,2011). Farrel et al (2019; 2017) has been working on the deprescription guidelines for drugs such as antipsychotics, benzodiazepines and proton pump inhibitors, aimed at supporting health professionals involved in care, identifying and safely managing adverse drug withdrawal reactions (Farrel et al., 2019; 2017).

The second most frequent DRP was non-adherence $(22,4 \%)$. In other studies, we found a large variation of 36 to $55 \%$ (Gokoel et al., 2020; Chisholm-Burns et al, 2016; Joost et al, 2014). It was noticed by pharmacists during the appointment that 
patients valued the use of immunosuppressants more and believed that they would have a greater benefit in adhering to this therapy than to the adjuvant. According to Loghman-Adham (2003), the patient's perception of treatment benefit is among the factors associated with low adherence. Thus, patients believe that immunosuppressive drugs are the most beneficial for their health, investing more in the use of these drugs to treat the concomitant diseases (Loghman- Adham, 2003). In addition,the etiology of nonadherence is multifactorial, with the strongest risk factors including past nonadherence and being an adolescent or young adult (Gokoel et al, 2020). DRP related to nonadherence were linked to use of concomitant medications and not to immunosuppressants.

Another factor indirectly related to the greater adhesion to the immunosuppressants is due to the ease of scheduling of return medical appointments, situation not experienced for other chronic diseases. This is because the follow-up of renal transplant patients is part of the provision of highly complex clinical services, which has the most delineated organizational guidelines and is little affected by the lack of professionals. Therefore, in low complexity outpatient services, such as in the case of prevalent chronic diseases (hypertension, diabetes, etc.), Brazilian National Health System (SUS) users report disruption in care, lack of clinical professionals and other problems, which makes it difficult to access and monitoring of treatment. These findings corroborate with the findings of Santana (2013) on SUS perception by different actors in the legislative and care context. Thus, irregular follow-up of concomitant diseases may decrease medication adhesion (Santana, 2013).

Thirty-one DRP were resolved, demonstrating that the CMM is an effective strategy for the resolution of DRP. In a study of patients with Chronic Obstructive Pulmonary Disease (COPD), in which PW method was used, patient follow-up was done in a similar way to this study (without the collaboration of the local pharmacists), 53.1\% of DRP were solved. In contrast, Lee et al (2016) when performing CMM in a Clinical Pharmacy Service in a Transplant Outpatient Clinic achieved 100\% resolution of DRP. It should be noted that in this study, the fact that having a pharmacist in the multidisciplinary team may have contributed to the high rate of DRP resolution. In the present study, as in Detoni et al (2017), the pharmacists who provided the CMM service were external from the study institution that could be a limitation. However, the number of interventions accepted (51,02\%), close to that found by Detoni et al (2017) (55.2\%), was considerable and shows that although the CMM service was performed by outside pharmacists to the multidisciplinary team of the outpatient clinic transplantation, acceptance of the interventions was positive (Detoni et al., 2017).

The most accepted pharmaceutical interventions were those that depended only on guidance on the correct use of medicines. The modification the acetil salicilic acid administration schedule is important to ensure its effectiveness, as the use of tacrolimus were well accepted. Regarding the guidance for suspending treatment with omeprazole, it is clear that the majority of patients suspended after the pharmaceutical appoitment, as they reported that they no longer used it frequently. The rest of patients who did not accept this intervention, forwarded this information to the prescriber, who opted to continue the treatment with the proton pump inhibitor.

The stratification of outcomes and early intervention were reported in few studies that followed and identified DRP in renal transplant patients demonstrating a field to be explored by health professionals, especially pharmacists. In addition to an expressive value of DRP solved, the CMM service was able to improve patients' clinical status, which shows that DRP resolution directly reflects on the health condition improvement of the renal transplant patient. Studies in other specialties have been able to demonstrate that CMM can improve the patient's clinical situation. However, in renal transplant patients we do not have this data for comparison, reinforcing the importance of this study (El Raichani et al.,2019; Lee et al.,2016).

The high number of "excellent" answers to item 5 and 7 demonstrates involvement and trust in the guidance given by the pharmacist. According to Bonadiman et al (2018), the studies on the user satisfaction of pharmaceutical services point out that the existing pharmacist-patient relationship and the environment are important elements that can play a key role in 
satisfaction. Regarding the environment, in the transplantation outpatient clinic, the place for the appointments was appropriate; the appointments were carried out in the offices, with total privacy, which led to the greatest number of "excellent" answers to item 9. Deserves attention the fact that the patients attended stayed for a long time in the outpatient clinic waiting for medical appointment, with this, the pharmacists used this moment of waiting to perform the appointments, using the necessary time to listen to the patient's report with tranquility, which may have reflected the higher frequency of "excellent" answers to item 12.

This work corroborates other studies that have shown that satisfaction with health services offered is linked to different dimensions that encompass not only the technical quality but the attention received and the interpersonal quality of care (Bonadiman et al.,2018; Arruda et al.,2017; Batbaatar et al., 2017, Foppa et al., 2014). The majority of the patients who attended CMM began to understand the role of the pharmacist in the management of pharmacotherapy and the importance of this service in health care, as well as the construction of a relation between patient and professional. The link between patient and professional is one of the pillars for the establishment of a relationship of trust, where, through an active listening, identifies health needs and, in this way, contributes to the effectiveness of pharmaceutical interventions (Foppa et al., 2014) It is important to highlight a point brought by the patients and that reflected in the satisfaction, it refers to the contribution in the management of pharmacotherapy. Some patients reported that appointments with the pharmacist were important for elucidating doubts and understanding about the drugs used in the treatment. According to Modes and Gaíva (2013), there is greater satisfaction on the part of the users of health services when they are offered space to solve doubts (Modes and Gaíva, 2013).

This result can be explained by pharmaceutical care, a theoretical framework used by the pharmacist in the CMM consultations, which is patient centered, focus in patient's relationship with the medication, approaching the individual in an integral way, in the search for understanding social and family issues which may be contributing to or making difficult the therapy (ACCP, 2021, Oliveira, 2011).

It should be noted that the CMM was very well received by the patients, which reinforces the importance of the continuity of this service, which, therefore, requires a pharmacist in the outpatient team of this hospital. Soeiro et al. (2017) describes an association between continuity of care and patient satisfaction (Brasil,2021; Soeiro et al.,2017).

There was no evidence of a patient's prior evaluation as to what they believed to be the pharmaceutical clinical service offered and what skills were important for the application of the same. Correr et al (2009) states that this absence of previous evaluation may lead the patient to have low expectations regarding the service and may contribute to the increase of the satisfaction observed (Correr et al.,2009)

Due to few publications that evaluate the pharmaceutical interventions in renal transplant patients in Brazil, it is suggested that this work was configured as an important step of this professional performance in individuals with chronic diseases (Gnatta et a.,2019). Successful experiences of clinical pharmacist performance have been reported in the follow-up of diabetic patients (Moura et al.,2013) and hypertensive patients with hypercholesterolemia (Planas et al., 2009) In addition, the main pharmaceutical clinical entities recommend the performance of this professional in the outpatient service due to the already consolidated clinical benefits, also in relation to the reduction of costs (Mourao et al.,2013; Planas et al.,2009)

The satisfaction survey portrays results that reflect the conditions of the services offered, over a period, and demonstrate the quality and also the need for continuous improvement of these. User suggestions are often applied in practice and help in continuous improvement of the service. Due to the relevance and the need to improve clinical pharmacy services, further studies on user satisfaction in a CMM service are necessary, both to evaluate the quality of the service provided and to guide improvements in the management of patients' pharmacotherapy, and in this specifically outpatient clinic reinforces the need to implant the CMM and the inclusion of a pharmacist in the team. 
The main limitations of the work refer to the availability of offices for patient care, due to the busy routine of the clinic. Another limiting point is that the research was carried out by pharmacists who were not part of the multidisciplinary team at the transplant clinic, which impacts on the capture of the patient and various logistical issues.

\section{Conclusion}

The present study demonstrated that CMM can detect DRP and achieve therapeutic goals, within a holistic approach and improve the patient's clinical situation through individualized interventions, as well as determining which individuals will benefit most from this pharmaceutical service.

The satisfaction of the user with the service provided is a valid quality indicator that will contribute to its improvement. It is recommended that polymedication be a priority criterion for CMM. Finally, the complexity of pharmacotherapy and the number of drug-related problems found demonstrates the necessity of the comprehensive medication management for renal transplant patients.

This work reinforces the performance of the clinical pharmacist in the face of adversity in the outpatient treatment of renal transplant patients, considerably improving their health status. Several studies have demonstrated positive clinical impact of CMM among patients belonging to diverse clinical conditions (Rodis et al., 2017; Nascimento, 2009; Planas, 2009) and also among renal transplant patients (Gnata et al., 2019; Pinheiro et al., 2019; Falcão et al, 2016). However, in Brazil, we did find few studies using CMM as a clinical method of pharmaceutical follow-up in this population, which reinforces the need for further research on this practice to strengthen Pharmaceutical Care in this segment.

It is believed that CMM for at least 12 months would be interesting to identify and prevent DRP in addition to definitively including other health professionals in the team who would contribute to improving the quality of life of these patients.

\section{References}

Acosta, A. M., Marques, G. Q., Levandovski, P. F., Peralta, J. P., \& Lima, M. A. D. D. S. (2016). Satisfação de usuários com cuidados de enfermagem em serviço de emergência: uma revisão integrativa. Reme: revista mineira de enfermagem. Vol. 20 (2016), e938.

American College of Clinical Pharmacy. Comprehensive medication management in team-based care. Available: https://www.accp.com/docs/positions/misc/CMM\%20Brief.pdf. Acess in: 20 de maio de 2020.

Arruda, C. A. M., \& Bosi, M. L. M. (2016). Satisfação de usuários da atenção primária à saúde: um estudo qualitativo no Nordeste do Brasil. InterfaceComunicação, Saúde, Educação, 21, 321-332.

Batbaatar, E., Dorjdagva, J., Luvsannyam, A., Savino, M. M., \& Amenta, P. (2017). Determinants of patient satisfaction: a systematic review. Perspectives in public health, 137(2), 89-101.

Berns, J. (2020). Patient education: dialysis or kidney transplantation-which is right for me?(Beyond the basics).

Bjerrum, L., Søgaard, J., Hallas, J., \& Kragstrup, J. (1999). Polypharmacy in general practice: differences between practitioners. British Journal of General Practice, 49(440), 195-198.

Bonadiman, R. L., Santanna, A. F., Brasil, G. A., Lima, E. M. D., Lenz, D., Endringer, D. C., \& Andrade, T. U. (2018). Nível de satisfação dos usuários e verificação do conhecimento dos farmacêuticos em farmácias públicas do Espírito Santo, Brasil. Ciência \& Saúde Coletiva, $23,627-638$.

Brasil. Ministério da Saúde. Portaria SAES/SCTIE MS nº 1, de 05 de janeiro de 2021. Avaiable: https://www.gov.br/saude/pt-br/assuntos/protocolos-clinicose-diretrizes-terapeuticas-pcdt/arquivos/2021/imunossupressao-em-transplante-renal-pcdt.pdf>. Acess em: 20 de dezembro de 2021.

Brito, D. C. S. D., Marsicano, E. O., Grincenkov, F. R. D. S., Colugnati, F. A. B., Lucchetti, G., \& Sanders-Pinheiro, H. (2015). Stress, coping and adherence to immunosuppressive medications in kidney transplantation: a comparative study. Sao Paulo Medical Journal, 134, $292-299$.

Chisholm-Burns, M. A., Spivey, C. A., Tolley, E. A., \& Kaplan, E. K. (2016). Medication therapy management and adherence among US renal transplant recipients. Patient preference and adherence, 10, 703 .

Cipolle, R. J., Strand, L. M., \& Morley, P. C. (2012). Pharmaceutical care practice: the patient-centered approach to medication management. McGraw Hill Professional. 
Correr, C. J., Pontarolo, R., Melchiors, A. C., Souza, R. A. D. P., Rossignoli, P., \& Fernández-Llimós, F. (2009). Satisfação dos usuários com serviços da farmácia: tradução e validação do Pharmacy Services Questionnaire para o Brasil. Cadernos de Saúde Pública, 25, 87-96.

de Oliveira, I. D. G., dos Reis, P. M., Reis, E. A., Gomes, K. B., Mota, A. P. L., \& Chemello, C. (2021). Integração da farmacogenética do tacrolimo ao gerenciamento da terapia medicamentosa em pacientes com transplante de rim. Research, Society and Development, 10(10), e52101018589-e52101018589.

Detoni, K. B., Oliveira, I. V., Nascimento, M. M., Caux, T. R., Alves, M. R., \& Ramalho-de-Oliveira, D. (2017). Impact of a medication therapy management service on the clinical status of patients with chronic obstructive pulmonary disease. International journal of clinical pharmacy, 39(1), 95-103.

El Raichani, L., Du, Q., Mathieu, A., Almassy, S., Lalonde, L., Berbiche, D., \& Cardinal, H. (2019). Development and validation of PART (Pharmacotherapy Assessment in Renal Transplant Patients) criteria to assess drug-related problems in an outpatient renal transplant population: A cross-sectional study. Pharmacology research \& perspectives, 7(1), 000453.

Elaine, W. Y., Bauer, S. R., Bain, P. A., \& Bauer, D. C. (2011). Proton pump inhibitors and risk of fractures: a meta-analysis of 11 international studies. The American journal of medicine, 124(6), 519-526.

Falcão Lima, L., Cardoso Martins, B. C., de Oliveira, F. R. P., de Andrade Cavalcante, R. M., Pinto Magalhães, V., Milen Firmino, P. Y., ... \& Rabelo Néri, E. D. (2016). Orientação farmacêutica na alta hospitalar de pacientes transplantados: estratégia para a segurança do paciente. Einstein (16794508), 14(3).

Farrell, B., \& Mangin, D. (2019). Deprescribing is an essential part of good prescribing. American family physician, 99(1), 7-9.

Farrell, B., Pottie, K., Thompson, W., Boghossian, T., Pizzola, L., Rashid, F. J., ... \& Moayyedi, P. (2017). Deprescribing proton pump inhibitors: evidencebased clinical practice guideline. Canadian Family Physician, 63(5), 354-364.

Foppa, A. A. (2014). Qualificação do serviço farmacêutico clínico a partir dos dados de seguimento farmacoterapêutico a indivíduos com Doença de Parkinson.

Gnatta, D., Keitel, E., \& Heineck, I. (2019). Interventions performed by clinical pharmacist in the renal transplant ambulatory care. Revista Brasileira de Farmácia Hospitalar e Serviços de Saúde, 10(3), 355-355.

Gokoel, S. R., Gombert-Handoko, K. B., Zwart, T. C., van der Boog, P. J., Moes, D. J. A., \& de Fijter, J. W. (2020). Medication non-adherence after kidney transplantation: a critical appraisal and systematic review. Transplantation Reviews, 34(1), 100511.

Ho, S. W., Teng, Y. H., Yang, S. F., Yeh, H. W., Wang, Y. H., Chou, M. C., \& Yeh, C. B. (2017). Association of proton pump inhibitors usage with risk of pneumonia in dementia patients. Journal of the American Geriatrics Society, 65(7), 1441-1447.

Isetts, B. J., Schondelmeyer, S. W., Artz, M. B., Lenarz, L. A., Heaton, A. H., Wadd, W. B., ... \& Cipolle, R. J. (2008). Clinical and economic outcomes of medication therapy management services: the Minnesota experience. Journal of the American Pharmacists Association, 48(2), 203-214.

Joost, R., Dörje, F., Schwitulla, J., Eckardt, K. U., \& Hugo, C. (2014). Intensified pharmaceutical care is improving immunosuppressive medication adherence in kidney transplant recipients during the first post-transplant year: a quasi-experimental study. Nephrology Dialysis Transplantation, 29(8), 1597-1607.

Jorge, M. S. B. (2007). Avaliação da qualidade do Programa Saúde da Família no Ceará: a satisfação dos usuários. Revista baiana de saúde pública, 31(2), 256-256.

Larson, L. N., Rovers, J. P., \& MacKeigan, L. D. (2002). Patient satisfaction with pharmaceutical care: update of a validated instrument. Journal of the American Pharmaceutical Association (1996), 42(1), 44-50.

Lee, P. H., Fan, P. Y. W., \& Kee, T. Y. S. (2016). Medication therapy management by pharmacists in a kidney transplant ambulatory clinic. Proceedings of Singapore Healthcare, 25(2), 117-121.

Leite, R. F., Silva, A. C. M., Oliveira, P. C. D., Silva, L. M. G. D., Pestana, J. M. D. A., Schirmer, J., \& Roza, B. D. A. (2018). Mensuração da adesão aos medicamentos imunossupressores em receptores de transplante renal. Acta Paulista de Enfermagem, 31, 489-496.

Loghman-Adham, M. (2003). Medication noncompliance in patients with chronic disease: issues in dialysis and renal transplantation. American Journal of Managed Care, 9(2), 155-173.

Manyama, T. L., Tshitake, R. M., \& Moloto, N. B. (2020). The role of pharmacists in the renal multidisciplinary team at a tertiary hospital in South Africa: Strategies to increase participation of pharmacists. Health SA Gesondheid (Online), 25, 1-7.

Mendonça, S. D. A. M., Melo, A. C., Pereira, G. C. C., Santos, D. M. D. S. S. D., Grossi, E. B., Sousa, M. D. C. V. B., ... \& Soares, A. C. (2016). Clinical outcomes of medication therapy management services in primary health care. Brazilian Journal of Pharmaceutical Sciences, 52, 365-373.

Modes, P. S. S. D. A., \& Gaíva, M. A. M. (2013). Satisfação das usuárias quanto à atenção prestada à criança pela rede básica de saúdea . Escola Anna Nery, 17, 455-465.

Molnar-Varga, M., Molnar, M. Z., Szeifert, L., Kovacs, A. Z., Kelemen, A., Becze, A., ... \& Novak, M. (2011). Health-related quality of life and clinical outcomes in kidney transplant recipients. American Journal of Kidney Diseases, 58(3), 444-452.

Mourao, A. O. M., Ferreira, W. R., Martins, M. A. P., Reis, A. M. M., Carrillo, M. R. G., Guimaraes, A. G., \& Ev, L. S. (2013). Pharmaceutical care program for type 2 diabetes patients in Brazil: a randomised controlled trial. International journal of clinical pharmacy, 35(1), 79-86.

Nascimento, Y. D. A., Carvalho, W. D. S., \& Acurcio, F. D. A. (2009). Drug-related problems observed in a pharmaceutical care service, Belo Horizonte, Brazil. Brazilian Journal of Pharmaceutical Sciences, 45, 321-330. 
Research, Society and Development, v. 11, n. 2, e49511226224, 2022

(CC BY 4.0) | ISSN 2525-3409 | DOI: http://dx.doi.org/10.33448/rsd-v11i2.26224

Planas, L. G., Crosby, K. M., Mitchell, K. D., \& Farmer, K. C. (2009). Evaluation of a hypertension medication therapy management program in patients with diabetes. Journal of the American Pharmacists Association, 49(2), 164-170.

Prates, D. S., Camponogara, S., Arboit, E. L., Tolfo, F., \& Beuter, M. (2016). Kidney transplant: perceptions from patients and healthcare professionals about kidney transplants. Rev Enferm UFPE, 10(4), 1264-72.

Prudencio, J., Cutler, T., Roberts, S., Marin, S., \& Wilson, M. (2018). The effect of clinical pharmacist-led comprehensive medication management on chronic disease state goal attainment in a patient-centered medical home. Journal of managed care \& specialty pharmacy, 24(5), 423-429.

Ramalho de Oliveira, D. (2011). Atenção Farmacêutica: da filosofia ao gerenciamento da terapia medicamentosa. RCN Editora: São Paulo, Brazil.

Rodis, J. L., Sevin, A., Awad, M. H., Porter, B., Glasgow, K., Hornbeck Fox, C., \& Pryor, B. (2017). Improving chronic disease outcomes through medication therapy management in federally qualified health centers. Journal of primary care \& community health, 8(4), 324-331.

Santana A. Avaliação do sistema único de saúde (SUS): um estudo fundamentado na percepção de diferentes atores em um município do sul de Minas Gerais. [Dissertação de Mestrado]. Lavras. Universidade Federal de Lavras (UFLA), 2013.

Soeiro, O. M., Tavares, N. U. L., Nascimento Júnior, J. M., Guerra Junior, A. A., Costa, E. A., \& Acurcio, F. A. (2017). Satisfação dos usuários com os serviços da assistência farmacêutica na atenção básica nos municípios brasileiros. Rev Saude Publica, 51(sSupl 2).

Stemer, G., \& Lemmens-Gruber, R. (2010). Clinical pharmacy services and solid organ transplantation: a literature review. Pharmacy world \& science, 32(1), 7-18.

Strand, L. M., Cipolle, R. J., Morley, P. C., \& Frakes, M. J. (2004). The impact of pharmaceutical care practice on the practitioner and the patient in the ambulatory practice setting: twenty-five years of experience. Current pharmaceutical design, 10(31), 3987-4001.

Vankova, B., Mala-Ladova, K., Kubena, A. A., Maly, J., \& Sulkova, S. D. (2018). Immunosuppressive therapy related adherence, beliefs and self-management in kidney transplant outpatients. Patient preference and adherence, 12, 2605.

Welch, E. K., Delate, T., Chester, E. A., \& Stubbings, T. (2009). Assessment of the impact of medication therapy management delivered to home-based Medicare beneficiaries. Annals of Pharmacotherapy, 43(4), 603-610.

Wittayanukorn, S., Westrick, S. C., Hansen, R. A., Billor, N., Braxton-Lloyd, K., Fox, B. I., \& Garza, K. B. (2013). Evaluation of medication therapy management services for patients with cardiovascular disease in a self-insured employer health plan. Journal of Managed Care Pharmacy, 19(5), 385-395. 